\title{
Evaluation of jet nebulisers for use with gentamicin solution
}

\author{
STEPHEN P NEWMAN, PETER GD PELLOW, MICHELLE M CLAY, \\ STEWART W CLARKE
}

From the Department of Thoracic Medicine, Royal Free Hospital, London

ABSTRACT Recently nebulised antibiotics (gentamicin and carbenicillin) have been used successfully to treat respiratory tract infection in patients with cystic fibrosis. No information exists, however, on the choice of nebuliser or the ideal mode of operation with antibiotic solutions, which are often viscous. The aerosol output, droplet size, and nebulisation time were assessed for four common brands of jet nebuliser (Bird, DeVilbiss, Inspiron, and Upmist) used to nebulise 2 $\mathrm{ml}(80 \mathrm{mg})$ and $4 \mathrm{ml}(160 \mathrm{mg})$ of gentamicin solution (Garamycin, Kirby-Warrick) at four compressed gas flow rates $\left(6,8,10\right.$, and $\left.121 . \mathrm{min}^{-1}\right)$. There were considerable variations between the nebulisers, DeVilbiss and Upmist being most efficient in the release of respirable $(<5 \mu \mathrm{m}$ diameter) droplets. Droplet size and nebulisation time were inversely proportional to gas flow rate. Aerosol output and nebulisation time were increased by raising the volume fill from 2 to 4 ml, although nebulisation time could still be restricted to 12 minutes or less with DeVilbiss and Upmist at $121 . \mathrm{min}^{-1}$. The output of drug in droplets of below $5 \mu \mathrm{m}$ diameter ranged from 7.2 (SE 0.4) to $71.4(4.3) \mathrm{mg}$, according to the type of nebuliser, flow rate, and volume fill. These studies suggest that for optimal drug delivery $4 \mathrm{ml}$ gentamicin solution should be nebulised either at a fixed flow rate of $10-121 . \mathrm{min}^{-1}$ or with a high flow compressor. Previous unsatisfactory clinical results with antibiotic aerosols may have been due in part to incorrect choice of nebuliser or inappropriate operating conditions, or both.

Treatment of chest disorders by inhaled drugs has several potential advantages over use of the oral or intravenous route in that a smaller dose of drug can often be used, there is a low incidence of systemic side effects, and the drug generally begins to act rapidly.' Antibiotics were first given by inhalation in $1946,{ }^{2}$ but for many years this form of treatment was considered to have no particular advantage in the treatment of respiratory tract infection. ${ }^{3}$ Recent studies, however, have shown an improvement in pulmonary function ${ }^{4}$ and a reduction in the frequency of hospital admission ${ }^{5}$ in selected patients with cystic fibrosis and Pseudomonas aeruginosa infection when treated regularly with nebulised antibiotics. Aerosol antibiotics offer the prospect of domiciliary treatment over relatively long periods, ${ }^{6}$ and their use is associated with higher sputum and

Address for reprint requests: Dr SP Newman, Department of Thoracic Medicine, Royal Free Hospital, London NW3 2QG.

Accepted 10 April 1985 lower serum concentrations of drug than are achieved with parenteral administration.?

Surprisingly little information exists on the output characteristics of nebulisers, and there is no information at all on the nebulisation of antibiotic solutions, which are more viscous than saline or water. The present study was carried out to assess the output, droplet size, and nebulisation time of four common brands of jet nebuliser used with a solution of gentamicin at four different compressed gas flow rates, as a basis for guidelines for the most efficient delivery of nebulised antibiotics.

\section{Methods}

Four brands of jet nebuliser were selected (Bird micronebuliser, DeVilbiss 646, Bard Inspiron mini-neb and Medic-Aid Upmist). Eight nebulisers of each brand were tested. Two volume fills of gentamicin solution (Garamycin, Kirby-Warrick) were used-namely, $2 \mathrm{ml}$ ( $80 \mathrm{mg}$ gentamicin) and 4 $\mathrm{ml}$ (160 mg gentamicin). The nebulisers and volumes of solution were chosen to conform with 
recent practice in the treatment of patients with cystic fibrosis with inhaled gentamicin at the Brompton Hospital, London. Nebulisation was performed with four different compressed gas flow rates $(6,8,10$ and $\left.121 . \mathrm{min}^{-1}\right)$ from an air cylinder. These flows were selected to correspond with the range of flows generated through nebulisers by most electrically driven compressors.

The nebuliser, fitted with mouthpiece, was weighed on a Mettler balance before and after the required solution had been added to the nebuliser reservoir by syringe. The nebuliser was then clamped within a fume cupboard and the solution nebulised to "dryness" at a constant flow rate. During nebulisation auxiliary air inlet holes and vents for exhaled air were sealed. Nebulisation time was measured by a stopwatch and was defined as $\mathbf{3 0}$ seconds after the last visible release of aerosol. The nebuliser was then weighed again to determine the mass of drug solution remaining in the nebuliser. Samples of gentamicin solution retained as a "dead" mass on baffles and internal walls after completion of nebulisation were collected and their concentration was measured with an Osmometer (Advanced Instruments Inc). The eight samples for a given brand of nebuliser with each volume fill and flow rate were pooled to make a composite sample for the osmolarity measurements. Pilot studies showed that the osmotic concentration was linearly related to the concentration of gentamicin. The mass of drug ( $\mathrm{mg}$ ) released as aerosol was calculated as

$$
\frac{M_{o} C_{o}}{\rho_{o}}-\frac{M_{f} C_{f}}{\rho_{f}}
$$

where $M_{o}$ and $M_{f}$ were respectively the mass of drug solution $(\mathrm{g})$ initially placed in the nebuliser reservoir and the "dead" mass of drug solution ( $\mathrm{g}$ ) remaining after nebulisation, $C_{o}$ and $C_{f}$ were the initial and final drug concentrations $\left(\mathrm{mg} \cdot \mathrm{ml}^{-1}\right)$, and $\rho_{o}$ and $\rho_{f}$ the initial and final solution densities (g.ml ${ }^{-1}$ ).

In a separate series of experiments the aerosol droplet size was measured $2.5 \mathrm{~cm}$ from the tip of the nebuliser mouthpiece with a Malvern Instruments 2600 HSD laser particle and droplet analyser. The instrument uses a $5 \mathrm{mw} 6328 \AA \mathrm{Ae}$-Ne laser beam of cross section $1 \mathrm{~cm}$, the laser light being diffracted by the aerosol spray at angles inversely proportional to droplet size on to a set of concentric detector rings. A microprocessor connected on line to the detector was used to analyse the light scattering data, and to calculate the mass of aerosol contained in each of 15 size bands on a logarithmic scale between 1.2 and $120 \mu \mathrm{m}$, a model independent computer program being used. The percentage of the aerosol mass contained in droplets of below $5 \mu \mathrm{m}$ diameter (the "respirable" range) and the mass median diameter (MMD, the droplet size such that half the aerosol mass is contained in smaller droplets and half in larger droplets) were calculated. Pilot studies showed that droplet size was identical for 2 and $4 \mathrm{ml}$ volume fills and did not change significantly during the course of nebulisation.

Finally, the mass of drug released as aerosol was multiplied by the percentage of the aerosol mass contained in droplets of below $5 \mu \mathrm{m}$ diameter to give the mass of gentamicin contained in these droplets.

The data were assumed to be non-normally distributed and were analysed by non-parametric techniques. ${ }^{8}$ The Wilcoxon rank sum test for paired data and the Friedman analysis of variance by ranks were used, a $p$ value of $\leqslant 0.05$ being taken to indicate statistical significance.

\section{Results}

MASS OF DRUG RELEASED AS AEROSOL

The mass of the initial solution varied from 2.05 to $2.19 \mathrm{~g}$ (78.6-84.3 $\mathrm{mg}$ gentamicin) for the $2 \mathrm{ml}$ fill and from 4.08 to $4.40 \mathrm{~g}$ (156.9-169.2 $\mathrm{mg}$ gentamicin) for the $4 \mathrm{ml}$ fill. The mass of solution retained in the nebuliser reservoir ranged from 0.44 to $1.26 \mathrm{~g}$ for the $2 \mathrm{ml}$ fill and from 0.52 to $2.28 \mathrm{~g}$ for the $4 \mathrm{ml}$ fill. The "dead" mass of the solution underestimated the true "dead" mass of gentamicin retained in the nebuliser because of the increase in concentration of this solution during nebulisation. The ratio of final to initial drug concentration ranged from 1.35 to 1.70 for the $2 \mathrm{ml}$ fill and from 1.45 to 1.96 for the 4 $\mathrm{ml}$ fill (table 1 ). This ratio did not vary significantly with compressed gas flow rate but was significantly $(p<0.01)$ higher for the $4 \mathrm{ml}$ fill than for the $2 \mathrm{ml}$ fill. The mass of gentamicin released as aerosol is shown in table 2 for each brand of nebuliser at each flow rate. With a $2 \mathrm{ml}$ fill the Bird nebuliser released a mean $34.5 \%$ of the drug dose, with $65.5 \%$ retained within the nebuliser. The drug output at $101 . \mathrm{min}^{-1}$ with the $2 \mathrm{ml}$ fill was lower than at the other three flow rates. With a $4 \mathrm{ml}$ fill the Upmist nebuliser released a mean $71.5 \%$ of the drug, with $28.5 \%$ retained. From 2.0 to 4.3 times more drug was released with the $4 \mathrm{ml}$ fill than with the $2 \mathrm{ml}$ fill $(p<0.01)$.

\section{AEROSOL SIZE MEASUREMENTS}

Aerosol sizing data are shown in table 3 . The percentage of the aerosol mass contained in droplets $<$ $5 \mu \mathrm{m}$ diameter rose significantly $(\mathrm{p}<0.01)$ for DeVilbiss, Inspiron, and Upmist nebulisers with increasing flow rate, while the MMD fell 
Table 1 Final drug concentrations ( $\left.m g . m l^{-1}\right)$ in the nebuliser reservoirs after nebulisation of 2 or 4 ml gentamicin solution (initially $40 \mathrm{mg} \cdot \mathrm{ml}^{-1}$ )

\begin{tabular}{|c|c|c|c|c|c|c|c|c|}
\hline \multirow[b]{2}{*}{ Type of nebuliser } & \multicolumn{4}{|c|}{$\begin{array}{l}2 \text { ml fill } \\
\text { Flow rate }\left(1 . \min ^{-1}\right)\end{array}$} & \multicolumn{4}{|c|}{$\begin{array}{l}4 \mathrm{ml} \text { fill } \\
\text { Flow rate (1.min }\end{array}$} \\
\hline & 6 & 8 & 10 & 12 & 6 & 8 & 10 & 12 \\
\hline $\begin{array}{l}\text { Bird } \\
\text { DeVilbiss } \\
\text { Inspiron } \\
\text { Upmist }\end{array}$ & $\begin{array}{l}54.4 \\
55.6 \\
58.4 \\
64.4\end{array}$ & $\begin{array}{l}62.0 \\
60.4 \\
65.2 \\
58.0\end{array}$ & $\begin{array}{l}57.2 \\
56.0 \\
63.6 \\
54.0\end{array}$ & $\begin{array}{l}58.4 \\
65.6 \\
68.0 \\
58.0\end{array}$ & $\begin{array}{l}59.2 \\
78.4 \\
71.2 \\
76.8\end{array}$ & $\begin{array}{l}65.6 \\
77.2 \\
69.2 \\
75.6\end{array}$ & $\begin{array}{l}58.0 \\
71.6 \\
74.0 \\
62.8\end{array}$ & $\begin{array}{l}64.0 \\
75.2 \\
74.8 \\
62.8\end{array}$ \\
\hline
\end{tabular}

significantly $(\mathrm{p}<0.01)$ for these three nebulisers as the flow rate increased. The change in aerosol size with flow rate was not significant for the Bird nebuliser. At 10 and $121 . \mathrm{min}^{-1}$ DeVilbiss and Upmist produced smaller droplets than the Bird and Inspiron nebulisers $(p<0.01)$.

DeVilbiss and Upmist also produced the greatest amounts of aerosol contained in droplets of below 3 $\mu \mathrm{m}$ and below $8 \mu \mathrm{m}$ diameter. For DeVilbiss the percentage of the aerosol mass in droplets of below 3 $\mu \mathrm{m}$ diameter rose from $13.4 \%$ (SE $3.4 \%$ ) to $33.9 \%$ $(2.5 \%)$ as the flow rate increased from 6 to $121 . \mathrm{min}^{-1}$, while the percentage of the aerosol mass in droplets of below $8 \mu \mathrm{m}$ diameter rose from $68.4 \%(3.8 \%)$ to $90.7 \%(3.3 \%)$.

Table 2 Mean (SE) mass of gentamicin ( $\mathrm{mg}$ ) released as aerosol, with mean percentages of the initial drug dose shown in parentheses below

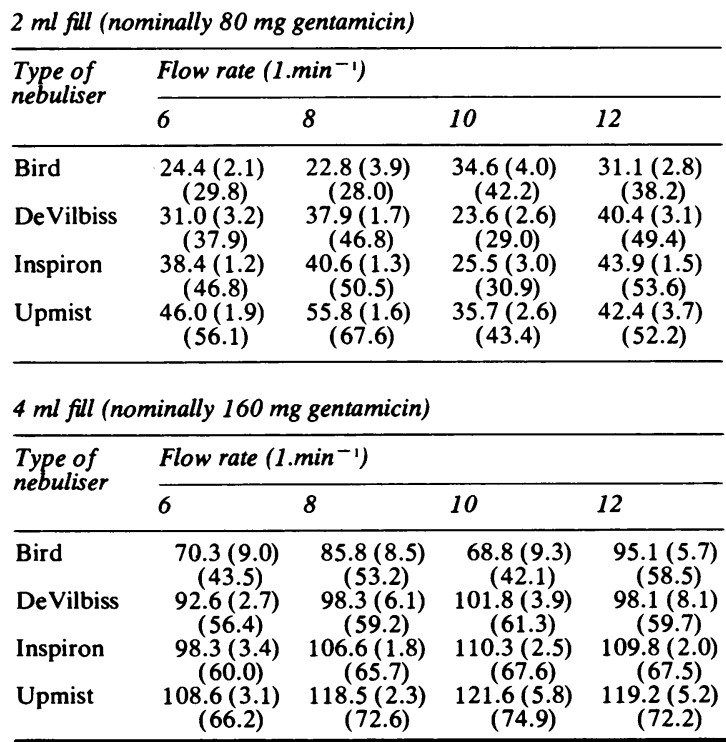

MASS OF DRUG IN DROPLETS $<5 \mu$ m DIAMETER There was a significant $(p<0.01)$ increase in the mass of gentamicin contained in droplets of below $5 \mu \mathrm{m}$ diameter as the flow rate was increased from 6 to $121 . \mathrm{min}^{-1}$, for both $2 \mathrm{ml}$ and $4 \mathrm{ml}$ volume fills (fig 1), primarily because of the reduction in droplet size with increasing flow rate. This mass had a minimum value of $7.2(0.4) \mathrm{mg}$ (mean $8.8 \%$ of the drug dose) for Inspiron with $2 \mathrm{ml}$ gentamicin solution at $61 . \mathrm{min}^{-1}$, and reached a maximum value of 71.4 (4.3) $\mathrm{mg}$ (mean $43.4 \%$ of the drug dose) for Upmist with a $4 \mathrm{ml}$ fill at $121 . \mathrm{min}^{-1}$. The percentage of the dose contained in droplets of below $5 \mu \mathrm{m}$ diameter was significantly $(p<0.01)$ higher with the $4 \mathrm{ml}$ fill.

\section{NEBULISATION TIME}

Nebulisation times are shown in figure 2. With the $2 \mathrm{ml}$ fill there was a significant $(\mathrm{p}<0.01)$ fall in nebulisation time as the flow rate was raised from 6 to $101 . \mathrm{min}^{-1}$, but then a rise in nebulisation time with the increase in flow from 10 to $121 . \mathrm{min}^{-1}$. At the highest flow rate, nebulisation times were less than 10 minutes for all four brands of nebuliser.

Table 3 Data on mean (SE) aerosol droplet size for gentamicin solution

\begin{tabular}{|c|c|c|c|c|}
\hline \multirow{2}{*}{$\begin{array}{l}\text { Type of } \\
\text { nebuliser }\end{array}$} & \multicolumn{4}{|c|}{ Flow rate $\left(1 . \mathrm{min}^{-1}\right)$} \\
\hline & 6 & 8 & 10 & 12 \\
\hline $\begin{array}{l}\text { Bird } \\
\text { DeVilbiss } \\
\text { Inspiron } \\
\text { Upmist }\end{array}$ & $\begin{array}{l}7.0(0.5) \\
6.6(0.3) \\
8.4(0.3) \\
7.2(0.1)\end{array}$ & $\begin{array}{l}6.2(0.3) \\
5.5(0.3) \\
7.0(0.1) \\
6.0(0.2)\end{array}$ & $\begin{array}{l}5.9(0.3) \\
4.7(0.3) \\
6.5(0.3) \\
5.2(0.2)\end{array}$ & $\begin{array}{l}5.8(0.3) \\
4.0(0.3) \\
6.3(0.6) \\
4.2(0.1)\end{array}$ \\
\hline \multicolumn{5}{|c|}{ Percentage of aerosol mass in droplets $<5 \mu \mathrm{m}$} \\
\hline \multirow{2}{*}{$\begin{array}{l}\text { Type of } \\
\text { nebuliser }\end{array}$} & \multicolumn{4}{|c|}{ Flow rate $\left(1 . \mathrm{min}^{-1}\right)$} \\
\hline & 6 & 8 & 10 & 12 \\
\hline $\begin{array}{l}\text { Bird } \\
\text { DeVilbiss } \\
\text { Inspiron } \\
\text { Upmist }\end{array}$ & $\begin{array}{l}32.4(3.9) \\
31.3(3.7) \\
18.8(1.0) \\
25.7(1.3)\end{array}$ & $\begin{array}{l}38.6(3.0) \\
44.6(4.3) \\
29.1(1.3) \\
38.6(1.6)\end{array}$ & $\begin{array}{l}42.0(3.3) \\
55.5(4.7) \\
36.5(2.1) \\
48.6(1.5)\end{array}$ & $\begin{array}{l}43.6(2.7) \\
64.8(4.7) \\
41.0(3.3) \\
59.7(1.3)\end{array}$ \\
\hline
\end{tabular}


$2 \mathrm{ml}$ fill (nominal $80 \mathrm{mg}$ )

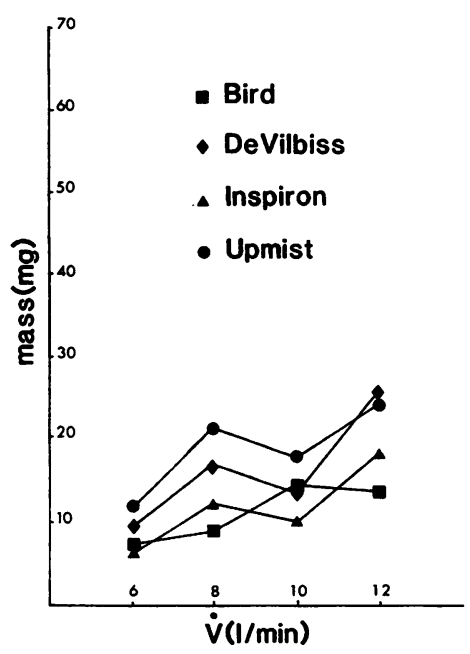

$4 \mathrm{ml}$ fill (nominal $160 \mathrm{mg}$ )

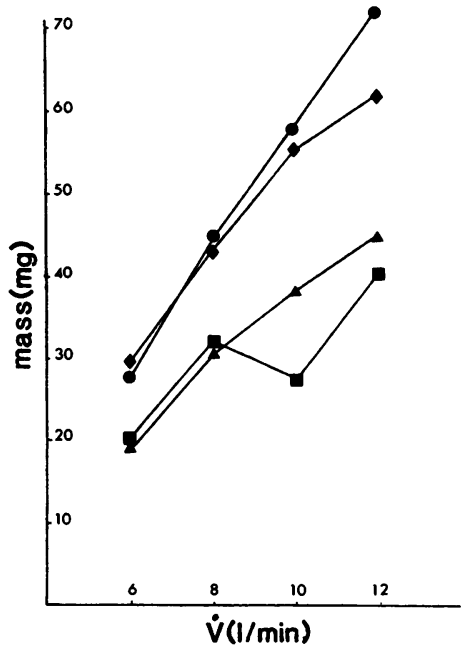

Fig 1 Average mass of gentamicin contained in droplets of less than 5 um diameter plotted as a function of compressed air flow rate for 2 and $4 \mathrm{ml}$ volume fills.

$2 \mathrm{ml}$ fill (nominal $80 \mathrm{mg}$ )

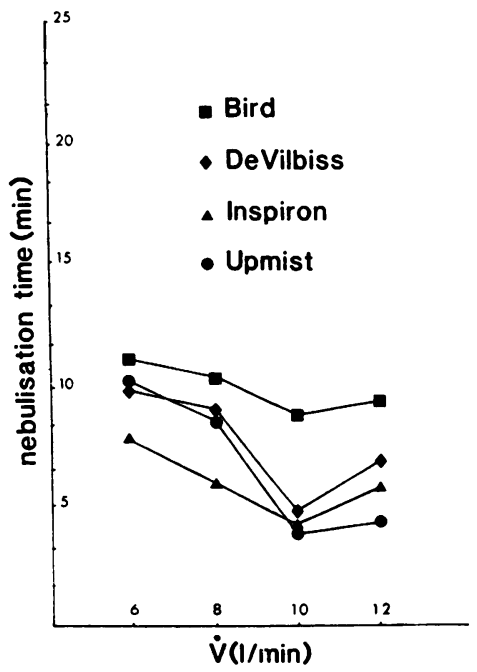

$4 \mathrm{ml}$ fill (nominal 160mg)

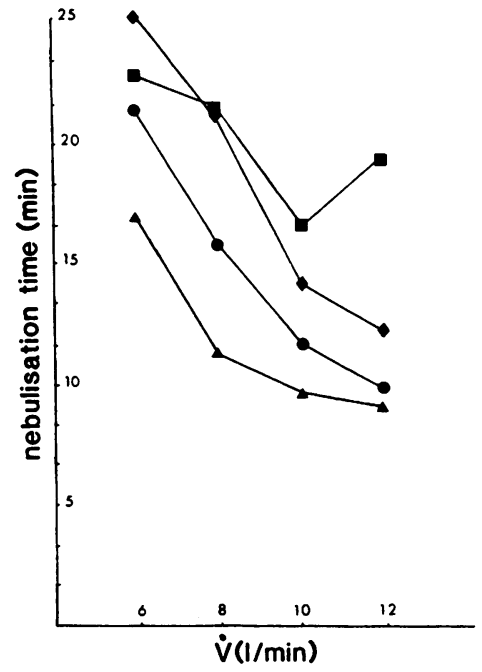

Fig 2 Average nebulisation time plotted as a function of compressed air flow rate for 2 and $4 \mathrm{ml}$ volume fills. 
With the $4 \mathrm{ml}$ fill there was a significant $(\mathrm{p}<0.01)$ negative correlation between nebulisation time and flow rate for the DeVilbiss, Upmist, and Inspiron nebulisers. At $121 . \mathrm{min}^{-1}$, nebulisation time averaged 9 minutes 50 seconds for Upmist and 12 minutes for DeVilbiss. Nebulisation time increased in proportion to the rise in volume fill from $2 \mathrm{ml}$ to $4 \mathrm{ml}$.

\section{Discussion}

The results show that there is a wide variation in the output of gentamicin aerosol droplets of less than $5 \mu \mathrm{m}$ diameter and in nebulisation time depending on the type of nebuliser used, the volume fill, and the compressed gas flow rate. There was a 10 fold difference between the most and the least efficient delivery systems (means $7.2 \mathrm{mg}$ versus $71.4 \mathrm{mg}$ gentamicin), suggesting that patients might sometimes be underdosed when relatively inefficient systems are used. Previous unsatisfactory clinical results with antibiotic aerosols may have been due in part to the use of relatively poor nebulisers and administration systems, rather than to any inherent failure of the topical antibiotic to work effectively within the bronchial tree.

Our findings confirm that there is a reduction in droplet size with increasing compressed gas flow rate, ${ }^{y-12}$ and simultaneously a reduction in nebulisation time. ${ }^{13}$ As shown previously, aerosol release is more efficient when the volume fill is increased. ${ }^{13}$ These previous studies, however, were performed with other types of nebuliser solution having physical properties different from those of antibiotic solutions (viscosities about $50 \%$ higher than that of normal $(0.9 \%)$ saline-unpublished observations) and their results could not be extrapolated automatically to gentamicin. For instance, with gentamicin, nebulisation times were higher and droplet sizes larger ${ }^{12}{ }^{13}$ than those observed for normal saline nebulised by Inspiron and Upmist nebulisers at 6 and $81 . \mathrm{min}^{-1}$. Variations in the output characteristics of nebulisers according to the physical properties of the drug solution have been predicted on theoretical grounds. ${ }^{14}$ is Our studies were performed with nebulisers clamped firmly in a fume cupboard with auxiliary air holes closed. While patients do not use nebulisers in precisely this fashion, our concerns were, firstly, to compare the relative merits of different brands of nebuliser, volume fills, and flow rates in an entirely standardised manner and, secondly, to prevent unpleasant antibiotic sprays from being released other than from the mouthpiece.

It is not known whether aerosol antibiotics should be delivered preferentially to the distal or proximal parts of the bronchial tree, and hence the ideal droplet size for these aerosols has yet to be determined precisely. We have therefore assessed nebulisers for their ability to produce "respirable" $(<5 \mu \mathrm{m}$ diameter) droplets," although some of these droplets will be deposited in the oropharynx and some will be exhaled. Smaller or larger aerosols might be more effective in the treatment of respiratory tract infections, but the most efficient nebulisers (DeVilbiss and Upmist) operating at 10-12 1.min ${ }^{-1}$ also optimised the quantities of gentamicin released in droplets of less than 3 and $8 \mu \mathrm{m}$ diameter. The percentage of the gentamicin dose contained in droplets of less than $5 \mu \mathrm{m}$ diameter ranged from $8.8 \%$ to $43.4 \%$ of the dose. These percentages are in broad agreement with the percentages of the aerosol dose deposited in the lungs from nebulisers, which have been estimated variously in the range $1-32 \% . .^{16-19}$

Aerosol delivery was enhanced at the higher flow rates $\left(10-121 . \mathrm{min}^{-1}\right)$, which are approximately equal to the flows generated through nebulisers by the most powerful compressors available for domiciliary use. Back pressures of at least $20 \mathrm{lb} / \mathrm{in}^{2}$ $(138 \mathrm{kPa})$ are needed to sustain these flow rates. Flows in the 10-12 $1 . \mathrm{min}^{-1}$ range have a second, most important advantage, in that nebulisation times are reduced. In practice, patients are found to tolerate treatment times of up to 10 minutes, but above this their compliance deteriorates. Extra care must be taken in assembling nebuliser systems for use with flows of $101 . \mathrm{min}^{-1}$ or more to prevent the tubing blowing off the nebuliser, compressor, or air cylinder during treatment.

When the volume fill was doubled from $2 \mathrm{ml}$ ( 80 $\mathrm{mg}$ ) to $4 \mathrm{ml}$ ( $160 \mathrm{mg}$ ), up to 4.3 times more drug was released as aerosol, since a smaller proportion of the drug dose was retained within the nebulisers themselves. A substantial rise in drug output would also be anticipated if $2 \mathrm{ml}$ gentamicin solution was diluted to $4 \mathrm{ml}$ with water or saline. While drug release was more efficient with a $4 \mathrm{ml}$ fill, nebulisation times were doubled and might have become too large for comfortable treatments with some types of nebuliser. With $4 \mathrm{ml}$ solution nebulised at 12 1. in $^{-1}$, however, nebulisation times averaged only 10 and 12 minutes with Upmist and DeVilbiss respectively. Further, these were the times taken to nebulise to "dryness." In practice, treatment might be stopped somewhat earlier (for instance, when nebulisation becomes intermittent), although it is not always possible to detect accurately the point at which this occurs.

In summary, DeVilbiss and Upmist were the most efficient of the brands of nebuliser tested, especially when used to nebulise $4 \mathrm{ml}(160 \mathrm{mg})$ gentamicin solution at $10-121 . \mathrm{min}^{-1}$. Several other promising 
brands of nebuliser are also available. These include models with cylindrical liquid feeds around the air inlet, which are less likely to become blocked by drug residue; and also models with integral valve systems adjacent to the mouthpiece for conducting away exhaled antibiotic via tubing to an exhaust. Studies are now in progress to assess the use of these models with antibiotic solutions.

This work was supported by a grant from the Cystic Fibrosis Research Trust. We should like to thank Dr ME Hodson, Dr R Stead, Dr B Hughes, Miss D Gaskell, and Miss B Webber of the Brompton Hospital for their advice. We are also grateful to Kirby-Warrick Pharmaceuticals Ltd for the supply of gentamicin solution.

\section{References}

1 Newman SP, Clarke SW. Therapeutic aerosols I. Physical and practical considerations. Thorax 1983;38: 881-6.

2 Southwell N. Inhaled penicillin in bronchial infections. Lancet 1946;ii: 225-7.

3 Williams MH. Steroid and antibiotic aerosols. Am Rev Respir Dis 1974;110:122-7.

4 Hodson ME, Penketh ARL, Batten JC. Aerosol carbenicillin and gentamicin treatment of Pseudomonas aeruginosa infection in patients with cystic fibrosis. Lancet 1981;ii: 1137-9.

5 Wall MA, Terry AB, Eisenberg J, McNamara M. Inhaled antibiotics in cystic fibrosis. Lancet 1983;i: 1325.

6 Hoiby N. The management of Pseudomonas chest infections - the way forward. In: Lawson D, ed. Cystic fibrosis: horizons. Chichester: John Wiley, 1984:8795.

7 Batten JC, Matthew DJ. The respiratory system. In:
Hodson ME, Norman AP, Batten JC, eds. Cystic fibrosis. London: Balliere Tindall, 1983:105-31.

8 Siegel S. Non-parametric statistics for the behavioural sciences. Tokyo: McGraw-Hill Kogakusha, 1956.

9 Davis SS. Physico-chemical studies on aerosol solutions for drug delivery. I. Water-propylene glycol studies. International Journal of Pharmaceutics 1978; 1:71-83.

10 Mercer TT, Goddard RF, Flores RL. Effect of auxiliary air flow on the output characteristics of compressed-air nebulisers. Ann Allergy 1969; 27:211-7.

11 Sterk PJ, Plomp A, Van der Vate JF, Quanjer PH. Physical properties of aerosols produced by several jet and ultrasonic nebulisers. Bull Eur Physiopathol Respir 1984;20:65-72.

12 Clay MM, Pavia D, Newman SP, Clarke SW. Factors influencing the size distribution of aerosols from jet nebulisers. Thorax 1983;38:755-9.

13 Clay MM, Pavia D, Newman SP, Lennard-Jones T, Clarke SW. Assessment of jet nebulisers for lung aerosol therapy. Lancet 1983;ii:592-4.

14 Gorman WG, Hall GD. Inhalation aerosols. In: Swarbrick J, ed. Current concepts in the pharmaceutical sciences: dosage form, design and bioavailability. Philadelphia: Lea and Febiger, 1973:97-148.

15 Mercer TT. Production of therapeutic aerosols. Principles and techniques. Chest 1981;80, suppl:813-8.

16 Asmundsson T, Johnson RF, Kilburn KH, Goodrich JK. Efficiency of nebulisers for depositing saline in human lung. Am Rev Respir Dis 1973;108:506-12.

17 Lin MS, Hayes TM, Goodwin DA, Kruse SL. Distal penetration in radioaerosol inhalation with an ultrasonic nebuliser. Radiology 1974;112:443-7.

18 Dolovich MB, Killian D, Wolff RK, Obminski G, Newhouse MT. Pulmonary aerosol deposition in chronic bronchitis: intermittent positive pressure breathing versus quiet breathing. Am Rev Respir Dis 1977; 115: 397-402.

19 Lewis RA, Fleming JS, Balachandran W, Tattersfield A. Particle size distribution and deposition from a jet nebuliser: influence of humidity and temperature. Clin Sci 1981;62:5P (abstract). 